\title{
Inclusion of Interest Rate Risk In Credit Risk On Bank Performance: Evidence In Indonesia
}

\author{
Julia Safitri¹, Suyanto², Maximus Loenardo Taolin ${ }^{3}$, Sri Lestari Prasilowati4 \\ 1,2,4 Sekolah Tinggi Ilmu Ekonomi IPWI Jakarta, Indonesia \\ ${ }^{3}$ Universitas Timor, Nusa Tenggara Timur, Indonesia
}

\section{INFO ARTIKEL JEL Classification :}

L10, G32

\section{Keywords :}

liquidity, bank performance, intersest rate risk, credit risk, monetary theory, financial intermediation theory

\begin{abstract}
This study aims to empirically examine the effect of liquidity on bank performance through the inclusion of interest rate risk on credit risk (INRISK) as a mediator. Where the inclusion of interest rate risk in credit risk (INRISK) is a novel concept developed from the synthesis of monetary theory, financial intermediation theory and liquidity theory, as an attempt to mediate the research gap between the effect of liquidity on bank performance. This study uses panel data with 30 companies as samples and uses the study period from 2010 to 2018, resulting in 270 observational data. All samples are banking companies listed on the IDX. The analytical tool used in this study was PLS-Sem with the WarpPLS 5.0 application.
\end{abstract}

\begin{abstract}
ABSTRAK
Penelitian ini bertujuan untuk menguji secara empiris pengaruh likuiditas terhadap kinerja bank melalui dimasukkannya risiko suku bunga pada risiko kredit (INRISK) sebagai mediator. Dimana dimasukkannya risiko suku bunga dalam risiko kredit (INRISK) adalah konsep baru yang dikembangkan dari sintesis teori moneter, teori intermediasi keuangan dan teori likuiditas, sebagai upaya untuk menengahi kesenjangan penelitian antara pengaruh likuiditas terhadap kinerja bank. Penelitian ini menggunakan data panel dengan 30 perusahaan sebagai sampel dan menggunakan periode penelitian dari 2010 hingga 2018, menghasilkan 270 data observasi. Semua sampel adalah perusahaan perbankan yang terdaftar di BEI. Alat analisis yang digunakan dalam penelitian ini adalah PLS-Sem dengan aplikasi WarpPLS 5.0.
\end{abstract}

\section{Introduction}

Bank can be defined through their functions in the economy, services offered to customers and their existence in law. (Berentsen et al., 2007) A bank is an intermediary institution that collects funds from the public in the form of deposits and channels them back to the community in the form of credit or other forms in order to accelerate the overall economic growth of a country. Banking in developing countries has become one of the institutions that play a very important role in domestic economic activities because it becomes one of the sources of funds needed for domestic market activities when other funding sources such as the capital market are still weak and limited so they have not been able to provide adequate funding sources for economic activity and investment (Saci et al., 2009).

(Wall, 1987) Banks are one type of financial institution, and thus are part of the financial system, so that in carrying out its 
function as an economic agent, it is influenced by macro factors and internal factors of banks or bank specific factors. Risk management is the essence of the implementation of prudential principles in managing banks, in a changing environment banks are faced with a number of risks, for example: credit risk, liquidity risk, exchange rate risk, market risk and only the bank is able to manage risk that can survive successfully (Powers et al., 2007) Risk management increases volatility (risk) in exchange rates, interest rates and commodity prices. This increased risk has triggered the need for new financial instruments and analytical tools to manage risk, credit risk is a risk that promises cash flow from loan income and other securities owned by financial institutions that may not be fully paid. Credit risk is very dominant in the composition of the capital adequacy ratio (capital adequacy ratio), where $70 \%$ of capital is allocated for credit risk and $30 \%$ for market risk and operational risk. Thus credit risk is the main cause of bank failures and risk is most visible in the face of bank managers (Garr, 2013).

Determination of interest rates in developing countries in the last decade, the issue of interest rates much discussed by economists. From empirical evidence, one of them (Gubareva dan Borges, 2016) can be seen that there is a positive relationship between the level of development in the financial sector and the economic situation of developing countries. The issue of interest rates is also included in the discussion relating to financial development. Each country has different interest rate problems, depending on the country's circumstances. One of them is the problem of determining interest rates, this problem is different for each different country.

Demirgunes and Ucler (2017) state that the problem of the relationship of deposits (deposit funds) with credit demand, should consider the effects that may arise on the growth of sources of funds as a result of the granting of credit, because if the provision of credit has no influence on the growth of sources of funds in the sense of not being able to grow the source of funds, then one day the bank will stop giving credit because its potential will be exhausted. To be able to provide the possibility of growing sources of funds, credit should be given to sectors that have many activities.
Olagunju et al. (2012), Cornett et al. (2011) if a bank's liquidity level is high, the profitability level will decrease. Conversely, if the bank experiences a low level of liquidity, it will cause an increase in the level of profitability. Some research results show the influence of LDR on ROA is significantly positive where the LDR increases, the ROA will increase (Jara-Bertin et al., 2014), (Ahmad, 2016).

Reserve requirements (RR) or legal reserve requirements (LRR) in Indonesia are known as the Statutory Reserves (GWM) is a minimum deposit that must be maintained in the form of demand deposits at Bank Indonesia for all banks. LRR or GWM is an instrument of Bank Indonesia to make monetary policy in controlling inflation. Exchange rates (exchange rates) and the amount of money in circulation. As for the banks themselves, besides having to meet operational needs if the customer is going to take their savings in cash. Thus in addition to maintaining the reserve requirement, banks must also maintain their cash ratios, the amount of which depends on the calculation or needs of each bank, currently ranging from $0.5 \%$ to $1.25 \%$ of third party funds (DPK). CAR is a capital ratio that shows the ability of banks to provide funds for business development needs and to accommodate the risk of loss of funds caused by bank operations. CAR shows the extent to which a decline in bank assets can still be covered by available bank equity. The higher CAR, the more capital owned by banks to cover the decline in assets.

Previous studies related to bank performance where the variables used were liquidity, capital adequacy and monetary policy. The findings produced differed views, some of the differences are shown below.

Wood and Skinner's research (2018) using a sample of banking companies namely Barbados banks in 1991-2015 shows that bank-specific factors such as capital adequacy, liquidity, and bad loans have a significant positive effect on bank performance, namely return on assets. Ahmad (2016) the purpose of this paper is to determine the relationship between liquidity and performance in banks, which found that there is a positive relationship between liquidity and performance, which means that 
if the company needs to focus on positive liquidity management with company performance. Paleni et al. (2017) by using secondary data derived from the 2011-2015 financial statements. The results of this study indicate that by using a significance level of 0.05 namely CAR, LDR and NPL simultaneously has a positive and significant effect on ROA.

Macharia and Timothy (2013) this study found that with a positive relationship between liquidity and performance in commercial banks in Kenya, liquidity was found to be a determining factor in profitability of commercial banks in Kenya for many years. This study recommends that the financial management of commercial banks in maintaining a balance between the level of liquid assets and long-term assets to strengthen each conflicting goal by maintaining adequate liquidity and sustainable profitability. In addition, the determined liquidity requirements need to be maintained and strengthened because liquidity is found to be positive towards profitability and stability as well as the growth of commercial banking from all financial and economic sectors.

Lartey et al. (2013) in this study explains that there is a positive relationship between liquidity and bank performance on the Ghana stock exchange in the 2005-2010 period, when banks have adequate liquid assets, performance will improve. Liquidity helps banks minimize risks and financial crises. The bank can absorb any unexpected possibilities.

Inconsistent research results are shown from several studies which state that liquidity has a negative effect on performance, (Mohanty1 and Krishnankutty2, 2018) the banking sector in India plays an important role in the country's development. This study aims to identify the performance that is responsible for driving the return on assets (ROA) of the bank. In 46 banks for 17 years (1999-2015) through the panel method, it was found that the loan to deposit ratio had a negative relationship with return on assets. The fact that the banking environment in India is different from other countries. Banks in India have higher income costs.

Zaineldeen (2018) this study aims to examine the relationship between liquidity and profitability in the Palestinian banking sector to contribute to the development of the financial sector. The relationship between liquidity and profitability between 2010-2016 was tested using the normal distribution test, there was a negative relationship between liquidity and profitability. Banks in Palestine have played an important role in influencing financial policies to serve the Palestinian people financially and to diversify the national economy. To ensure adequate liquidity for Palestinian banks to conduct their business efficiently, it is necessary to adopt a general framework of liquidity management and statistically evaluate banks to balance bank resources and use of funds.

Huang and Pan (2016) research conducted on 13 commercial banks in the 2009-2011 period this paper studied the relationship of liquidity and bank performance in China, that liquidity has a negative relationship with performance. Therefore it is necessary to improve the governance structure and profitability by optimizing the capital structure of commercial banks. Ikpefan and Kazeem (2013) in this study through regression analysis found that the loan to deposit ratio has a negative relationship with return on assets and is statistically significant at $1 \%$ and $5 \%$. The negative relationship between the loan to deposit ratio and ROA shows that with increasing ratio, the return on company assets will decrease and vice versa. This means that the loan to deposit ratio does not increase the profit ratio or the bank's performance ratio.

\section{Literature Review}

\subsection{Liquidity Prefrence Theory}

Liquidity Preference Theory, which was originally developed by (J.M. Keynes, 1946) analyzes the equilibrium interest rate through the interaction of money supply with the public aggregate demand for holding money. Keynes assumes that most individuals hold wealth in only two forms: money and bonds. According to Keynes, money is equivalent to currencies and demand deposits, which pay no interest or pay very low interest, but are very liquid and can be used for transactions. Liquidity preference theory is based on the demand and supply of money supply and the view that all financial decisions emphasize the money aspect of liquidity. This is consistent 
with the opinion expressed by (Modigliani, 1944) which states that people who have borrowed goods from others and sometimes they have asked for compensation for services rendered. Rewards are called rent, the price of borrowing someone else's property. Whereas (Tobin, 1958) states that interest is the amount of funds, valued from money, received by the lender (creditor), while the interest rate is the ratio of interest to the loan amount. So the interest rate is the price of borrowing money to use purchasing power. Interest rates are one of the variables in the economy that is always closely watched because of its broad impact. Interest directly affects people's daily lives and has an important impact on the health of the economy in terms of consumption, credit, bonds, and savings.

\subsection{Monetary Theory}

This theory includes the classical theory developed by (David Hume 1752). The essence of this theory is that changes in commodity prices will be directly proportional to the change in the Amount of Money Circulating (JUB). The condition of Full Employment itself is motivated by the thinking of classical economists (JB. Say), who said that supply will always create demand, so that the economy will never experience under emplyoment.

The purchasing power of money is very much determined by the price of the item, the higher the price of the commodity (goods and services), the less commodity can be obtained with some money, which means the purchasing power (Purcahsing Power) will decrease. Vice versa, the lower the price of a commodity, the more quantities of commodity can be obtained. This theory includes the classical theory developed by (David Hume 1752). The essence of this theory is that changes in commodity prices will be directly proportional to the change in the Amount of Money Circulating (JUB). The condition of Full Employment itself is motivated by the thinking of classical economists (JB. Say), who said that supply will always create demand, so that the economy will never experience under emplyoment.

\subsection{Basel}

After the global crisis in 2008-2009, Basel considered that the capital required in Basel II needed to be renewed. In addition, Basel also considered that stress testing conducted by banks was considered insufficient so that many banks experienced problems in dealing with crisis conditions. Therefore, Basel decided to influence Basel II. The three pillar system in Basel II remains in force, coupled with a number of new regulations in general to deal with crisis conditions. Indonesia is a member of the G20, and has stated its commitment to follow the decision regarding the adoption of Basel III in Indonesian banks. Basel III focuses on capital quality, liquidity, procyclicatily issues, and systemic problems. Basel capital accord is a set of regulations designed to keep the banking industry in a country so that it can continue to run and be well managed. It began with the establishment of the Basel Committee on Banking Supervision (BCBS) in 1974 by the Governor of the Central Bank of the G-10 countries and issued the International Convergence of Capital Measurement and Capital Standards (Basel I) rules which were implemented in Indonesian banks in 1992.

\subsection{Financial Intermediation}

Financial intermediation is the key to understanding why profits are supervised by an intermediary which is not carried out by the depositor (Diamond, 1984). Financial intermediation allows the best contracts and large allocations as a positive role in the financial intermediation process. In general loans and deposits with no high leverage result in a low probability of default..

A number of other theories including (Allen dan Santomero, 1997), (Bikker et al., 2003), further said that why banks, and financial intermediaries in general can exist because they can manipulate liquidity risks that occur from the flow of funds from surplus parties (depositors) by becoming agents of those who need funds (borrowers). The risk arises because of the occurrence of asimetric information, contracting costs, and scale mismatches between the liquidity of the fund and the liquidity of the parties that need funds. The basic theory of intermediation from financial intermediary institutions is to see banks as solutions to these problems, because banks have a comparative advantage about all information about the crediting values of debtors (Pyle, 1971), (Scholes et al., 1976) banks are more able to monitor debtors than 
Individual creditors (Leland dan Pyle, 1977), banks can provide greater liquidity than funds collected from the household sector and business sector and can issue demand deposits that can be exchanged for funds (Fama, 1980).

\subsection{Bank Risk Management}

Risk management in banking is theoretically defined as the logical development and implementation of plans to deal with potential losses. Usually the focus of risk management practices in the banking industry is managing the institution's exposure to losses or risks and to protect the value of assets (Tursoy, 2018). The banking industry has long seen the problem of risk management as the need to control four risks from risk exposures, namely, credit, interest rates, foreign exchange, and liquidity risk (Pyle, 1999). Bank risk management is a process in which managers meet the need to identify key risks, obtain operational risk steps that are consistent, understandable, choose which risks should be reduced and which ones are increased and in what ways, and establish procedures to monitor the risk positions that are produced (Ratnovski, 2013).

\subsection{Interest Rate Theory}

The classical flow theory is called "The Pure Theory of Interest". According to this theory, high and low interest rates are determined by the demand and supply of capital. So capital has been considered the price of the opportunity for capital use. Just like the prices of goods and services, the high and low are determined by the demand and supply, so also the high and low capital interest is determined by the demand and supply of capital (Goodfriend, 1991).

According to the classical theory, saving is a function of the interest rate in the economy which will affect saving. Means that people's desire to save is very dependent on the interest rate. The higher the interest rate, the greater the desire of the community to save or the community will be compelled to sacrifice expenses in order to increase the amount of savings. So the interest rate according to the classic is a reward received by someone for saving or a gift received by someone for delaying consumption. Investment is a function of interest rates. The higher the interest rate, the less will the people want to invest. Because the expected return on investment will be more than the interest rate (the cost of using the loan) (L., 1998).

\subsection{Proposition Model}

This study proposes a proposition as the basis for developing a model that is built from a variety of literature reviews, by placing a series of important decision concepts for banking companies in improving company performance (Tripathi dan Ghosh, 2012). The development of propositions begins with the state of the art as the basis for developing the concept of novelty proposed in this study, namely the interaction of interest rate risk in credit risk as a mediator between liquidity and bank performance. Based on the description above, the proposition proposed in this study is the inclusion of interest rate risk in credit risk (INRISK) is the synthesis of credit risk by considering market risk which is formulated by adding up credit risk and interest rate risk. Inclusion of interest rate risk in credit risk (INRISK) acts as a mediator of liquidity on bank performance, so that inclusion of interest rate risk in low credit risk (INRISK) can improve bank performance.

INRISK is a model of combining credit risk with market risk which is formulated by adding up credit risk and interest rate risk, low Inrisk can improve bank performance.

Picture 2.1 Pictograph Proposition

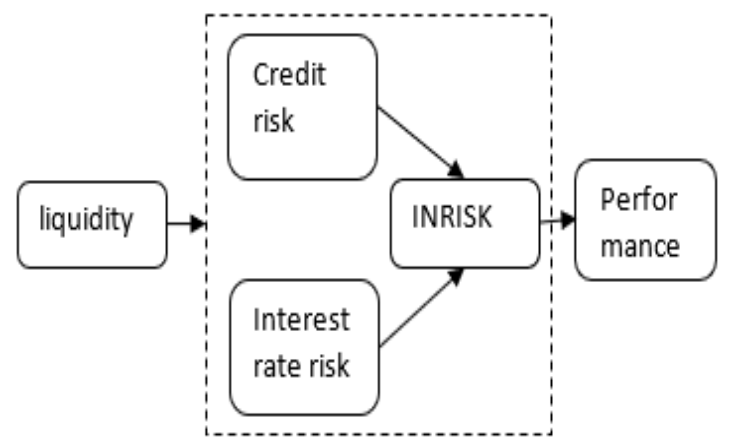

\subsection{Basic Theoretical Model}

Through the concept of the proposed proposition, a basic theoretical model is then built. Proposition or concept of Interest Rate Inclusion in Credit Risk is proposed to fill the gap of previous research between liquidity and bank performance. Conceptually, "Interest Rate Inclusion in Credit Risk" is proposed because it is a business phenomenon that is happening. Keynes's interest rate 
determination theory says that the interest rate is merely a monetary phenomenon in which the formation takes place on the money market. This means that the interest rate is determined by the supply and demand for money. Barro (1983) states that bank management must understand the interest rate risk inherent in the assets and liabilities component of the bank's balance sheet, determine whether the interest rate risk is still in line with the bank's strategy and not exceed the limit, and assess whether the method the bank has for controlling risk interest rates are sufficient. Based on the description above, the basic theoretical model of research can be described as follows:

\section{The Proposed Grand Theoritical Model}

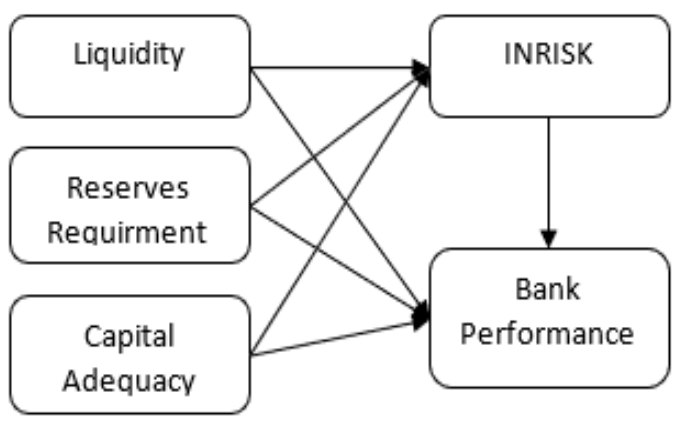

The relationship between bank liquidity as measured by a loan to deposit ratio (LDR) with profitability on return on assets (ROA) has been studied in banks in Europe with positive significant results, corporate liquidity is the main determinant of corporate profitability. This finding shows that the greater the amount of credit extended, the greater the interest income received by banks so that the return on assets increases. The results of this study also showed that the greater the source of idle bank funds (idle funds) the smaller the profitability. National banking is a financial service industry whose existence will be determined not only by competitive market conditions between businesses banking itself, but also the success of the banking business is determined by the dynamics of the movement of the real sector of the production environment as service users banking. If the economic conditions in a slow situation, the banking business face a relatively high risk of bad debts, resulting in monetary policy Bank Indonesia is a stimulus that might be used by national banks to manage businesses more stable. The stability of the national banking business is determined by the performance of Return on Assets (ROA) obtained from the difference between savings interest, public deposits and other costs with interest on loans. For the stability of the banking business, ROA is not merely a technical problem, but more than that is the implementation of the rate of repayment of credit from public loans. The level of security of credit risk is part of a very complex banking business, which is largely determined by the stability of the national economy. Based on such loan risk, Bank Indonesia's monetary policy determines the stability of the banking business to be sustainable in the future. Capital Adequacy Ratio (CAR) as one indicator of a bank's ability to cover a decline in assets as a result of losses suffered by banks, the size of the CAR is determined by the ability of banks to generate profits and the composition of funds allocated to assets in accordance with the level of risk In accordance with Bank Indonesia Circular Letter No. 11/3 / DPNP dated January 27, 2009 regarding Calculation of Risk Weighted Assets (ATMR) for Operational Risk Using the Basic Indicator Approach (PID) that CAR ratio takes into account credit risk, operational risk, and CAR market risk determined by Bank Indonesia is minimal $8 \%$ as stated in $\mathrm{BI}$ Regulation Number 10/15 / PBI / 2008 Article 2 Paragraph 1 and in line with standards set by the Bank of International Settlements (BIS).

\subsection{The Hypothesis}

The bank's financial performance in this study is profitability with a return on assets (ROA) indicator calculated from profit before tax divided by total assets (Marozva, 2015), (Idowu et al., 2002). ROA provides information on net profit generated per unit of monetary assets invested so that it also provides information on the ability of bank management to invest in bank assets. Liquidity conducted by banks is measured by a loan to deposit ratio, running effectively, (Toby 1,2014 ) if the bank can channel all of its sources of funds in the form of credit after being calculated with compulsory reserves and liquidity. This shows that the more loan to deposit ratio increases, the more productive the source of funds the bank has, the bank's profit can increase. 
Hypothesis 1: Loan to Deposit Ratio has a positive effect on Return on Assets.

Return on assets (ROA) focuses the company's ability to obtain earnings in the company's operations, (Mawardi, 2005). ROA is one of the important indicators to measure the effectiveness of the Bank in generating profits by utilizing the assets owned, the greater the ROA the higher the rate of return this means the bank's business is developing in a healthy manner. Bank Indonesia has currently implemented a combination of the use of monetary policy through indirect instruments with setting SBI interest rates and indirect instruments for controlling the money supply through setting the Statutory Reserves (GWM) in national banks.

Hypothesis 2: Reserves Requirment have a positive effect on Return On Assets.

Capital adequacy standards for banks operating internationally are a major concern for regulatory banks throughout the world. Therefore, the Bank for International Settlements (BIS) established a framework for measuring capital adequacy for banks in the ten (G10) banking industries of countries in the world. Capital adequacy standards affect bank performance (Ezike dan Oke, 2013).

Hypothesis 3: Capital Adequacy Ratio has a positive effect on Return on Assets

The ability of financial liquidity between companies tends to vary. (Schmaltz, 2009) based on the criteria of a company that has a strong financial position is able to meet its financial obligations to outsiders in a timely manner, able to maintain adequate working capital conditions, able to pay interest and dividend obligations that must be paid, and maintain a safe debt credit position. The liquidity ratio aims to assess the company's financial ability to meet its short-term obligations and financial payment commitments. The higher the liquidity ratio, the better it will be for investors.

Hypothesis 4: Loan to Deposit Ratio has a negative effect on Return On Assets through the Interaction of Interest Rate Risk in Credit Risk (INRISK).

In theory, a decrease in interest rates will cause savings and deposit interest in banks to be unattractive. People will look for other alternatives with higher yields, namely the capital market. An increase in demand due to a decrease in interest will cause an increase in share prices and vice versa. For companies, a decrease in interest rates will make the cost of loan interest decrease so that it encourages expansion and increases in net profit. In the long run, an increase in net income can cause the stock market price to increase. This research was supported by (Bridenstine, 1953), (Timberlake, 1999), (Glocker dan Towbin, 2015).

Hypothesis 5: Reserves Requirment have a negative effect on Return On Assets through the Interaction of Interest Rate Risk in Credit Risk (INRISK).

Capital adequacy is a policy or regulation of a company or banking in handling its capital. Capital is funds invested by the owner in the context of establishing a business entity that is intended to finance the bank's business activities in addition to meeting regulations set by the monetary authority (Hrishikes Bhattacharya, 2013). Adequate capital can increase public confidence, because it indicates that banks can accommodate the possibility of loss risk that will be experienced by banks due to bank operational activities. That way, capital adequacy will have an impact on increasing profits or profitability of banks through loan interest. CAR is an indicator that is often used to measure the level of bank capital adequacy.

Hypothesis 6: Capital Adequacy Ratio has a negative effect on Return On Assets through the Interaction of Interest Rate Risk in Credit Risk (INRISK).

The first influence, IRR has a positive or direct effect on interest rate risk and negative or opposite direction to the level of the bank's ability to manage income received with costs incurred which are influenced by interest rates. If the IRR increases, it shows an increase in Interest Rate Sensitive Assets (IRSA) with a percentage greater than the percentage increase in Interest Rate Sensitive Liabilities (IRSL). This situation will increase interest rate risk if the interest rate decreases, which means there is a negative relationship, but the situation will reduce interest rate risk if the interest rate increases which means there is a positive relationship. The second effect, 
IRR can have a positive or negative relationship to ROA. A positive effect on ROA will occur if the IRR experiences an increase when interest rate trends also increase. Increased IRR indicates that the increase in IRSA has a greater percentage than the percentage increase in IRSL.

Hypothesis 7: Interaction of Interest Rate Risk in Credit Risk (INRISK) mediates the Loan to Deposit Ratio to Return On Assets.

\subsection{Empirical Research Model}

The empirical research model is based on hypotheses 1 through 7 , then the measurement steps for the variables mentioned follow the previous research. The empirical model of the study is presented in Figure 2 below.

Picture 2.2. Empirical Research Model

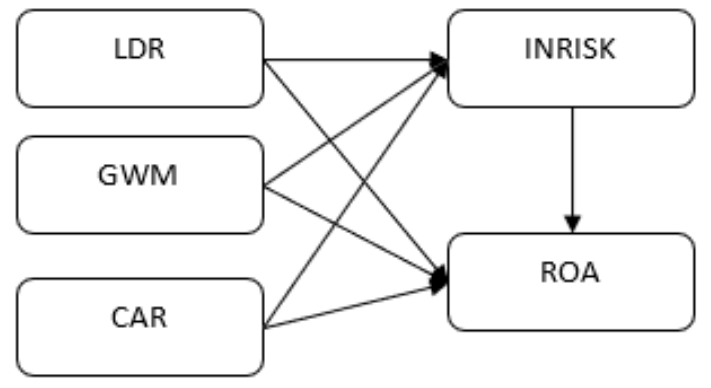

\section{Research Method}

\subsection{Data Sources}

The object of this research is banking companies listed on the stock exchange from 2010 to 2018. The type of data in this documentary is data in the form of financial statements of banking companies in Indonesia for the period 2010-2018. For the source of the data is secondary data, that is data obtained.

\subsection{Definition of Variable Operations}

The problem in this research is formulated into a simultaneous model. According to (Ferdinand 2014), a model formed through more than one dependent variable which is encapsulated by one or several independent variables, where the dependent variable when the same will act as an independent variable for other tiered relationships. In this study there are three variables namely, independent variables, dependent variables and mediating variables. Independent variables in this study, Monetary Policy, liquidity, capital adequacy. The dependent variable is financial performance. The mediating variable is the role of interest rate risk on credit risk.

\section{Dependent Variable}

1. Liquidity Banks that can carry out the intermediation function are banks that can collect savings and then distribute it in the form of credit in a balanced manner or in banking terms is a bank has a loan to deposit ratio (LDR) according to the target. The LDR of banks that are on target for commercial banks in Indonesia is a minimum of $78 \%$ and a maximum of 92\% (Bank Indonesia, 2013). Liquidity in this study was proxied by LDR (Schmaltz, 2009), (Shen et al., 2009), (Arif dan Nauman Anees, 2012), (Alzorqan, 2014), (Imbierowicz dan Rauch, 2014).

$\mathrm{LDR}=($ total credit $) /($ third party funds $) \mathrm{x}$ $100 \%$

2. Reserve requirements (RR) or legal reserve requirements (LRR) in Indonesia are known as the Statutory Reserves (GWM) is a minimum deposit that must be maintained in the form of demand deposits at Bank Indonesia for all banks. LRR or GWM is an instrument of Bank Indonesia to make monetary policy in controlling inflation (Arndt, 1979). Exchange rates (exchange rates) and the amount of money in circulation. As for the banks themselves, besides having to meet operational needs if the customer will take their deposits in cash. Thus in addition to maintaining the reserve requirement, banks must also maintain their cash ratios, the amount of which depends on the calculation or needs of each bank, currently ranging from $0.5 \%$ to $1.25 \%$ of third party funds (DPK).

Statutory Reserves $=$ current accounts with BI / third party funds $\mathrm{x} 100 \%$

3. CAR of a bank will be influenced by two main factors, namely the amount of capital owned by the bank and the amount of Risk Weighted Assets (ATMR) managed by the bank. This is due to the assessment of capital factors based on the ratio of Capital to Risk Weighted Assets (ATMR). (Khaled A. Zedan, 2017), (Anshika, 2016), who use CAR measurements for capital adequacy. 
Capital factor assessment is measured using the Capital Adequacy Ratio (CAR) with the following formula:

$\mathrm{CAR}=($ Bank Capital) $/$ (Risk Weighted Assets) $\mathrm{x} 100 \%$

\section{Dependent Variable}

The company's ability to generate profits indicates that there is cash flow. The ratio commonly used to analyze the profitability of banking companies is Return on Asset. Return On Assets is a ratio to measure the ability of banks to obtain a return on the utilization of their assets. This ratio is formulated as follows:

ROA $=($ Profit Before Tax $) /$ (Total Assets) $\mathrm{x}$ $100 \%$

\section{Mediation Variable}

Inclusion of interest rate risk in credit risk, which is obtained by the sum of the proxy credit risk and Raroc and market risk which in this study takes a proxy about interest rate risk, the interest rate risk. Credit risk Raroc is a measurement of credit risk for a portfolio using a statistical approach. Raroc (return adjusted risk on capital) is a tool in risk management in order to test a credit risk in the context of risk management in a bank. Raroc was popularized by Bankers Trust since 1979 which was then followed and used by various banks. According to Zaik et al. (1996) required measurement of risk with reasons for the purpose of risk management determining how much each transaction contributed to the total risk of the bank.

$$
\text { Raroc }=\frac{\text { Adjusted Income }}{\text { Capital at Risk }}
$$

Rate Sensitivity Asset (RSA) and Rate Sensitivity Liability (RSL) are the sensitivity of assets and liabilities in a group (bucket) that are determined against changes in interest rates. These assets and liabilities are re-valued (repriced or changed) according to or near market interest for a certain period of time in the future. Rate sensitivity is the sensitivity or sensitivity to changes in interest rates. Research using IR, (Yang et al., 2014), (Abdymomunov dan Gerlach, 2014), (Oberoi, 2017), (Chaudron, 2018).

$\mathrm{IRR}=(\mathrm{RSA}$ (rate sensitive assets) $) /(\mathrm{RSL}$

(rate sensitive liabilities)) x 100\%

\section{The Concept of Inclusion of Interest Rate Risk in Credit Risk.}

The next step integrates the dimension of interest rate inclusion in credit risk, where interest rate risk which is proxied by IRR (interest rate risk) is summed with credit risk that is proxied by Raroc, then the result is a proxy used as an indicator to measure inclusion Interest Rate Risk in Credit Risk.

In summary, the formulation of Interest Rate Inclusion in Credit Risk can be written and completed in the mathematical formulation as follows:

$$
\begin{aligned}
& {\left[\frac{R S A(\text { rate sensitive assets })}{R S L \text { (rate sensitive liabilities })}\right]+} \\
& {[\text { DF. } \delta \text { (DPK).(1-RR).EAD }]}
\end{aligned}
$$

Addition in the novelty concept is done because the greater the risk, the better the performance will be. Viewed from the variables that become the research gap, namely liquidity on performance, where liquidity uses a loan to deposit ratio proxy, if the greater the liquidity, the smaller the credit risk, but credit risk is related to interest rate risk which is part of market risk, so the liquidity high will affect credit risk which means that with interest rate risk the credit risk will be greater, mathematically the intended use to increase numbers.

\section{Result}

\begin{tabular}{|c|c|}
\hline Provisions & Conclusion \\
\hline Average & Fit \\
\hline $\operatorname{coefficient}(\mathrm{APC})=0.186$, & Fit \\
\hline$P<0.001$ & Fit \\
\hline Average & Fit \\
\hline $\begin{array}{l}\text { Square }(\text { ARS })=0.197, \\
P<0.001\end{array}$ & Fit \\
\hline Average Adj & \\
\hline $\begin{array}{l}\text { Square (AARS) }=0.186, \\
P,) .001\end{array}$ & Fit \\
\hline Average block & \\
\hline $\begin{array}{l}\mathrm{VIF}(\mathrm{AVIF})=1.146 \text {, acceptable } \\
\text { if }<=5 \text {, ideally }<=3\end{array}$ & \\
\hline Average full collinearity & \\
\hline $\begin{array}{l}\mathrm{VIF}(\mathrm{AFVIF})=1.208, \\
\text { acceptable if }<=5, \text { ideally } \\
<=3\end{array}$ & \\
\hline Tenenhaus & \\
\hline $\begin{array}{l}\mathrm{GoF}(\mathrm{GoF})=0.444, \quad \text { small } \\
>=0.1, \quad \text { medium }>=0.25, \\
; \operatorname{arge}>=0.36\end{array}$ & \\
\hline
\end{tabular}

\subsection{Test Model Fit Research}

Table 4.1 Model Fit Research 
Based on the results of the model fit as presented in the table above, it can be concluded that this research model is fit. This is also supported by the AVIF value of 1,219 and the AFVIF value of 1.581 which is smaller than 3.3, thus indicating that there is no multicollinity problem between indicators and between exogenous variables. The strength of the model prediction is shown by the GoF value of 0.598 so it can be concluded that the model prediction is very large because it is greater than 0.36 .

Full Collinearity VIF, R- Squared and Adjusted R-Squared.

Table 4.2. VIF, R Squared and Adjusted RSquared

\begin{tabular}{|c|c|c|c|c|c|}
\hline & $\begin{array}{l}\mathrm{LD} \\
\mathrm{R}\end{array}$ & $\begin{array}{l}\text { GW } \\
M\end{array}$ & $\begin{array}{l}\text { CA } \\
\text { R }\end{array}$ & $\begin{array}{l}\text { RO } \\
\mathrm{A}\end{array}$ & $\begin{array}{l}\text { INRI } \\
\text { SK }\end{array}$ \\
\hline $\begin{array}{l}\text { Full } \\
\text { collinea } \\
\text { rity } \\
\text { R- } \\
\text { Squared } \\
\text { Adj R- } \\
\text { Squared }\end{array}$ & $\begin{array}{l}1.3 \\
10\end{array}$ & $\begin{array}{l}1.05 \\
8\end{array}$ & $\begin{array}{l}2.1 \\
24\end{array}$ & $\begin{array}{l}1.0 \\
88 \\
0.1 \\
38 \\
0.1 \\
25\end{array}$ & $\begin{array}{l}2.324 \\
0.578 \\
0.573\end{array}$ \\
\hline
\end{tabular}

Source: warpPLS data processing 5.0

Based on the test results in the above table, the construct in this study is very good category because based on the rule of thumb is $<3.3$, which means the model is free from the problem of vertical, lateral and common method bias. Furthermore, to see variations that affect INRISK on R squared 0.578 which means the influence of variations in liquidity (LK), monetary policy (KM), Capital Adequacy (KMod) on INRISK by $57.8 \%$ and the remaining $42.2 \%$ is explained by other variables not included in this study. If seen from the rule of thumb for evaluating the structural model in this study, it is included in the strong category because it is greater than $\leq$ 0.25 . The adjusted $\mathrm{R}$ squared value for variations in the effect of liquidity, monetary policy, capital adequacy on performance by 0.573 or $57.3 \%$, the remaining $42.7 \%$ is explained by other variables not included in this research model. The rule of thumb for evaluating the structural model in this study is in the strong category, where the adjusted $\mathrm{R}$ squared of 0.573 is greater than $\leq 0.25$.

\section{Full Model Test}

Table 4.3. Path Coeffcicient and P-Value

\begin{tabular}{|l|l|l|}
\hline Path & $\begin{array}{l}\text { Coefficie } \\
\text { nt }\end{array}$ & P-Value \\
\hline LDR $\rightarrow$ ROA & 0.165 & $0.002^{* *}$ \\
GWM $\rightarrow$ ROA & 0.113 & $*$ \\
CAR $\rightarrow$ ROA & 0.128 & $0.015^{* *}$ \\
LDR $\rightarrow$ INRIS & 0.332 & $0.029^{* *}$ \\
K & 0.074 & $<0.001^{*}$ \\
GWM $\rightarrow$ INRI & -0.617 & $* *$ \\
SK & -0.189 & $0.054^{*}$ \\
CAR $\rightarrow$ INRIS & & $<0.001^{*}$ \\
K & & $* *$ \\
INRISK $\rightarrow$ RO & & $0.005^{* *}$ \\
A & & \\
\hline
\end{tabular}

Source: warpPLS data processing 5.0

Based on testing the path coefficient and P-value equation models in the table above, the results of the first hypothesis testing show that liquidity has a positive effect on bank performance. This is indicated by the LDR coefficient of 0.165 and p-value of 0.002 , consistent with the hypothesis, so that the first hypothesis is accepted. For testing the second hypothesis, monetary policy has a positive effect on bank performance, indicated by the coefficient value of GWM 0.113 and p-value 0.015 , so that the second hypothesis is accepted. Furthermore, capital adequacy (CAR) with a coefficient value of 0.128 and p-value of 0.029 where the third hypothesis of capital adequacy has a positive effect on bank performance (ROA) is accepted. Hypothesis seven shows that the interaction of interest rate risk to credit risk (INRISK) has a positive effect where the ROA coefficient value is 0.189 and p-value 0.005, this shows if hypothesis 9 is accepted. Full model test results can be seen in Figure 4.1 which shows the causality relationship between variables, in this case liquidity (LDR), monetary policy (GWM), capital adequacy (CAR) are independent variables and bank performance $(\mathrm{KB})$ is the dependent variable mediated by INRISK. 


\section{Picture 4.1 Full Model}

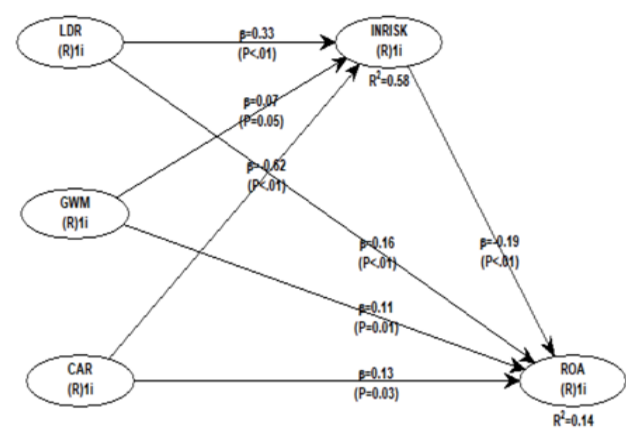

\section{Mediation Effect Test}

Table 4.4. Indirect Effect and Total Effect

\begin{tabular}{|l|l|l|}
\hline Indirect Effect & $\begin{array}{l}\text { Path } \\
\text { Coefficie } \\
\text { nt }\end{array}$ & $\begin{array}{l}\text { P- } \\
\text { Value }\end{array}$ \\
\hline LDR $\rightarrow$ INRISK $\rightarrow$ RO & -0.063 & 0.009 \\
$\mathrm{~A}$ & -0.014 & 0.084 \\
GWM $\rightarrow$ INRIK $\rightarrow$ RO & 0.117 & 0.006 \\
$\mathrm{~A}$ & & \\
$\mathrm{CAR} \rightarrow$ INRISK $\rightarrow$ RO & & \\
$\mathrm{A}$ & & \\
\hline Total Effect & Path & P- \\
& Coefficie & Value \\
\hline LDR $\rightarrow$ INRISK $\rightarrow$ RO & 0.102 & 0.071 \\
A & 0.099 & 0.028 \\
GWM $\rightarrow$ INRISK $\rightarrow$ R & 0.245 & $<0.00$ \\
OA & & 1 \\
CAR $\rightarrow$ INRISK $\rightarrow$ RO & \multicolumn{2}{|l}{} \\
A & & \\
\hline
\end{tabular}

Source: warpPLS data processing 5.0

Based on the results of testing the mediation effect in the table above the indirect effect coefficient for testing the hypothesis of $\mathrm{LDR} \rightarrow$ INRISK $\rightarrow$ ROA mediation is 0.063 with $\mathrm{p}$-value $0.009(\mathrm{p}<10 \%)$. These results explain that the value of INRISK is able to mediate the effect of liquidity on bank performance. In testing the direct path path $\mathrm{LDR} \rightarrow \mathrm{ROA}$ is significant at $0.002<1$. While the path / path direct relationship LDR $\rightarrow$ INRISK $<0.001$. Likewise, the path to path of INRISK $\rightarrow$ ROA is 0.005 . it can be concluded that there is a partial mediation in the relationship of liquidity (LDR) to bank performance (ROA) through INRISK as a partial mediation variable or partial mediation. Furthermore, based on the results of testing the mediation effect in table 4.4. indirect effect coefficient for testing the hypothesis five namely GWM $\rightarrow$ INRISK $\rightarrow$ ROA is -0.014 and the direct relationship GWM $\rightarrow$ ROA has a p-value of $0.015(>5 \%)$ is not significant, these results explain that there is no mediation in the relationship of monetary policy (GWM) to bank performance (ROA) through INRISK.

Testing the next hypothesis is hypothesis six, based on table 4.4 above shows the value of the indirect effect relationship CAR $\rightarrow$ INRISK $\rightarrow$ ROA of 0.0117 and p-value of 0.006 , explaining that the value of INRISK is able to mediate the effect of capital adequacy (CAR) on bank performance (ROA). Furthermore, the results of testing the path of direct capital adequacy (CAR) to bank performance (ROA) are significant 0.029 . While the direct path of capital adequacy (CAR) to INRISK is significant at $<0.001$. Through the results of this test it can be concluded that there is a full mediation on the relationship of capital adequacy (CAR) to bank performance (ROA) through INRISK as a partial mediation or partial mediation.

\section{Conclusion}

Based on the results of testing and analysis with WarpPLS 5.0, we get the following conclusions:

1. Goodnes of fit test shows the research model has a very good fit. The test results indicate that in the model there are no multicollinity problems between exogenous variables, nor is there a problem of causality in the model. The model is free from the contribution of $\mathrm{R}$ squared is negative and free from the presence of statistical suppression effects. So that the evaluation test for suitability / fit model is fulfilled and supported by available data.

2. Full Colinearity VIF Test and Variance Inflation Factors Test shows that in this study the model is free from 
the problem of vertical, lateral and common methods bias colinearity.

3. The effect size test shows the effect of the interaction of interest rate risk in credit risk (INRISK) on bank performance (ROA) producing the largest effect size of the overall relationship between other variables. This indicates that the role of INRISK can improve bank performance (ROA) where with the existence of INRISK all bank companies will be more careful in managing risk.

Table 5.1. Conclusion of Research Analysis Results

\begin{tabular}{|c|c|c|c|}
\hline No & $\begin{array}{l}\text { Hypothesis } \\
\text { Testing } \\
\text { Results }\end{array}$ & $\begin{array}{l}\text { P- } \\
\text { Value }\end{array}$ & Conclusion \\
\hline 1 & $\begin{array}{l}\text { Liquidity has a } \\
\text { positive effect } \\
\text { on bank } \\
\text { performance }\end{array}$ & 0.002 & $\begin{array}{l}\text { Accepted } \\
* * *\end{array}$ \\
\hline 2 & $\begin{array}{l}\text { Monetary has a } \\
\text { positive effect } \\
\text { on bank } \\
\text { performance }\end{array}$ & 0.015 & Accepted ** \\
\hline 3 & $\begin{array}{l}\text { Capital } \\
\text { adequacy has a } \\
\text { positive effect } \\
\text { on bank } \\
\text { performance }\end{array}$ & $<0.001$ & $\begin{array}{l}\text { Accepted } \\
* * *\end{array}$ \\
\hline 4 & $\begin{array}{l}\text { Liquidity } \\
\text { through } \\
\text { INRISK } \\
\text { negatively } \\
\text { affects bank } \\
\text { performance }\end{array}$ & $<0.001$ & $\begin{array}{l}\text { Accepted } \\
* * *\end{array}$ \\
\hline 5 & $\begin{array}{l}\text { Monetary } \\
\text { policy through } \\
\text { INRISK } \\
\text { negatively } \\
\text { affects bank } \\
\text { performance }\end{array}$ & 0.054 & Rejected \\
\hline 6 & $\begin{array}{l}\text { Capital } \\
\text { adequacy } \\
\text { through } \\
\text { INRISK } \\
\text { negatively } \\
\text { affects bank } \\
\text { performance }\end{array}$ & $<0.001$ & $\begin{array}{l}\text { Accepted } \\
* * *\end{array}$ \\
\hline
\end{tabular}

\begin{tabular}{|l|l|l|l|}
\hline 7 & $\begin{array}{l}\text { INRISK } \\
\text { mediates } \\
\text { liquidity on } \\
\text { bank } \\
\text { performance. }\end{array}$ & 0.005 & $\begin{array}{l}\text { Accepted } \\
* * *\end{array}$ \\
\hline
\end{tabular}

Source: WarpPLS data processing results 5.0 Note: $* * * \operatorname{Sig} 1 \% * * \operatorname{Sig} 5 \% * \operatorname{Sig} 10 \%$

\section{References}

Allen, F., \& Santomero, A. M. (1997). The theory of financial intermediation. Journal of Banking \& Finance, 21(11-12), 14611485.

Al-Tamimi, H. A. H., \& Al-Mazrooei, F. M. (2007). Banks' risk management: a comparison study of UAE national and foreign banks. The Journal of Risk Finance Incorporating Balance Sheet, 8(4), 394409.

Alzorqan, S. (2014). Bank liquidity risk and performance: an empirical study of the banking system in Jordan. Research Journal of Finance and Accounting, 5 (12): 155,64 ..

Ahmad, R. (2016). "A Study of Relationship between Liquidity and Profitability of Standard Charterd Bank Pakistan: Analysis of Financial Statement Approach". Global Journal of Management And Business Research.

Arif, A., \& Anees, A. N. (2012). Liquidity risk and performance of banking system. Journal of Financial Regulation and Compliance, 20(2), 182-195.

Arndt, H. W. (1979). Monetary policy instruments in Indonesia. Bulletin of Indonesian Economic Studies, 15(3), 107122.

Benston, G. J., \& Smith, C. W. (1976). A transactions cost approach to the theory of financial intermediation. The Journal of finance, 31(2), 215-231.

Berentsen, A., Camera, G., \& Waller, C. (2007). iMoney. Credit and Banking, jJournal of Economic Theory, 135(1), 171.

Bhattacharya, H. (2013). Capital Regulation And Rising Risk Of Banking Industry: A Financial Accounting Perspective. Academy of Banking Studies Journal, 12.

Bikker, J. A., Wesseling, S., \& Els, P. J. A. (2003). Intermediation, integration and 
internationalisation: a survey on banking in Europe: De Nederlandsche Bank.

Chaudron, R. F. (2018). Bank's interest rate risk and profitability in a prolonged environment of low interest rates. Journal of Banking \& Finance, 89, 94-104.

Chen, Y. K., Shen, C. H., Kao, L., \& Yeh, C. Y. (2018). Bank liquidity risk and performance. Review of Pacific Basin Financial Markets and Policies, 21(01), 1850007.

Cornett, M. M., McNutt, J. J., Strahan, P. E., \& Tehranian, H. (2011). Liquidity risk management and credit supply in the financial crisis. Journal of financial economics, 101(2), 297-312.

Culp, C. L., \& Neves, A. M. (1998). Credit and interest rate risk in the business of banking. Derivatives Quarterly, 4, 19-35.

Demirgüneş, K., \& Üçler, G. (2017). "Investigating the Relationship Between Liquidity and Financial Performance in Turkish Banking Sector: A Pre and Post 2008 Financial Crisis Assessment". Pada Global Financial Crisis and Its Ramifications on Capital Markets: Springer, 347-369.

Diamond, D. W. (1984). Financial intermediation and delegated monitoring. The review of economic studies, 51(3), 393-414..

Fama, E. F. (1980). Banking in the Theory of Finance. Journal of monetary economics, 6(1), 39-57..

Garr, D. K. (2013). Determinants of credit risk in the banking industry of Ghana. Developing Country Studies, 3(11), 64-77..

Goodfriend, M. (1990). Interest rates and the conduct of monetary policy. Federal Reserve Bank of Richmond Working Paper, (90-6).

Gubareva, M., \& Borges, M. R. (2016). Governed by the cycle: direct and inverted interest-rate sensitivity of emerging market corporate debt.

Huang, Z., \& Pan, H. (2016). A study on the impact of capital structure of China's listed commercial banks on profitability. Management \& Engineering, (22), 65.
Idowu, P. A., Alu, A. O., \& Adagunodo, E. R. (2002). The effect of information technology on the growth of the banking industry in Nigeria. The Electronic Journal of Information Systems in Developing Countries, 10(1), 1-8.

Ikpefan, O. A., \& Kazeem, B. L. O. (2013). The effect of merger on deposit money banks performance in the Nigerian Banking Industry. Journal of Applied Finance and Banking, 3(4), 105.

Imbierowicz, B., \& Rauch, C. (2014). The relationship between liquidity risk and credit risk in banks. Journal of Banking \& Finance, 40, 242-256.

Jara-Bertin, M., Moya, J. A., \& Perales, A. R. (2014). Determinants of bank performance: evidence for Latin America. Academia Revista Latinoamericana de Administración.

Lartey, V. C., Antwi, S., \& Boadi, E. K. (2013). The relationship between liquidity and profitability of listed banks in Ghana. International Journal of Business and Social Science, 4(3).

Leland, H. E., \& Pyle, D. H. (1977). Informational asymmetries, financial structure, and financial intermediation. The journal of Finance, 32(2), 371-387.

Marozva, G. (2015). Liquidity and bank performance. International Business \& Economics Research Journal (IBER), 14(3), 453-562.

Macharia, W. T. (2013). The relationship between profitability and liquidity of commercial banks in Kenya. A research project submitted in partial fulfilment of the requirements for the award of masters of business administration, University of Nairobi.

Mohanty, B. K., \& Krishnankutty, R. (2018). Determinants of profitability in Indian banks in the changing scenario. International Journal of Economics and Financial Issues, 8(3), 235.

Modigliani, F. (1944). Liquidity Preference and the Theory of Interest and Money,„Econometrica”,styczeń,[przedruk 
w:] H. Hazlitt (red.)(1960), The Critics of Keynesian Economics.

Oberoi, J. (2018). Interest rate risk management and the mix of fixed and floating rate debt. Journal of Banking \& Finance, 86, 70-86.

Olagunju, A., David, A. O., \& Samuel, O. O. (2012). Liquidity management and commercial banks' profitability in Nigeria. Research Journal of Finance and Accounting, 2(7-8), 24-38.

Paleni, H., Hidayat, S., \& Jatmiko, D. P. (2017). Determinants of Profitability: Evidence from Indonesian Firms. International Journal of Economic Perspectives, 11(3).

Pyle, D. H. (1971). On the theory of financial intermediation. The Journal of Finance, 26(3), 737-747.

Pyle, D. H. (1999). Bank risk management: theory. In Risk Management and regulation in banking (pp. 7-14). Springer, Boston, MA.

Ratnovski, L. (2013). Liquidity and transparency in bank risk management. Journal of Financial Intermediation, 22(3), 422-439..

Saci, K., Giorgioni, G., \& Holden, K. (2009). Does financial development affect growth?. Applied Economics, 41(13), 1701-1707.

Timberlake, R. H. (1999). The reserve requirement debacle of 19351938. FREEMAN-NEW YORKFOUNDATION FOR ECONOMIC EDUCATION-, 49, 23-24.

Tobin, J. (1958). Liquidity preference as behavior towards risk. The review of economic studies, 25(2), 65-86.

Toby, A. J. (2014). Financial fragility and performance of Nigerian banking institutions: An inter-temporal analysis. Journal of Applied Finance and Banking, 4(6), 137.

Tripathi, V., \& Ghosh, R. (2012). Interest rate sensitivity of banking stock returns in India. International Journal of Financial Management (ISSN: 2229-5690) Vol,2, 10-20.

Tursoy, T. (2018). Risk management process in banking industry.
Wall, L. D. (1987). FYI commercial bank profitability: some disturbing trends [2]. Economic Review-Federal Reserve Bank of Atlanta, 72(2), 24.

Wood, A., \& Skinner, N. (2018). Determinants of non-performing loans: evidence from commercial banks in Barbados. The Business \& Management Review, 9(3), 44-64.

Yang, H. F., Liu, C. L., \& Chou, R. Y. (2014). Interest rate risk propagation: Evidence from the credit crunch. The North American Journal of Economics and Finance, 28, 242-264.

Zaik, E., Walter, J., Retting, G., \& James, C. (1996). RAROC at Bank of America: from theory to practice. Journal of Applied Corporate Finance, 9(2), 83-93.

Zedan, K. A., \& Daas, G. (2017). Palestinian banks analysis using CAMEL model. International Journal of Economics and Financial Issues, 7(1), 351-357. 